\title{
4. Claiming spaces for acts of citizenship: recent experiences of activists in Morocco
}

\author{
Sylvia I. Bergh and Salima Ahmadou
}

\section{INTRODUCTION}

A new generation of young activists entered the political scene in Morocco in the spring of 2011 to demand democratic change. ${ }^{1}$ On 20 February 2011 , protests with a reported 300,000 participants were held in 53 towns simultaneously - something that had not been witnessed since the kingdom's independence. Two weeks later, King Mohamed VI announced the reform of the Constitution responding to the pressure generated by what came to be known as the February 20 Movement (F20M). A referendum on the new Constitution was held on 1 July 2011, in which 98.4 per cent of the voters voted in favour. While protests had continued throughout the period February to July 2011, they were attracting fewer people, especially after the King called for new parliamentary elections on 30 July 2011. During the elections, held on 25 November, the Islamist Justice and Development Party (PJD) emerged as the clear winner and Abdelilah Benkirane was appointed prime minister shortly afterwards. ${ }^{2}$

A key actor in the 'Arab Spring' in Morocco was the Moroccan Association of Human Rights (Association marocaine des droits humains, AMDH, created in 1979) which had a long track record of denouncing specific cases of human rights violations and boasted more than 90 regional branches. Since 2006, the AMDH and other non-governmental

1 According to Haim Malka, the February 20 movement (F20M) protesters called for a constitutional monarchy in which the monarch's political and economic power would be substantially diminished to a more symbolic role. They also called for socio-economic justice, equality and an end to corruption. See Haim Malka 'Power and Authority in Morocco', Adelphi Series 55 (2015) 452: 69.

2 Ahmed Benchemsi, 'Morocco's Makhzen and the Haphazard Activists', in Taking to the Streets: the Transformation of Arab Activism, eds. Lina Khatib and Ellen Lust (Baltimore: The John Hopkins University Press, 2014), 199. 
organisations (NGOs) had also been campaigning for economic justice, represented by the now defunct National Coordinating Committee against the High Cost of Living (Comité contre la cherté de la vie). Supported by leftist parties, labour unions and anti-globalisation groups, the AMDH organised a series of sit-ins to protest the increases in the price of staple goods and basic services such as transportation, water, and electricity. Based on the popular success of these protests, more than 70 local coordinating committees (tansiqiyyat mahalliyya) were set up, which soon functioned independently from the national structure. A group called ATTAC Maroc also gained popularity with its struggle against French companies (such as Lydec and Amendis) holding urban water and electricity concessions in Casablanca, Tétouan, and Tangier. ${ }^{3}$ More or less the same coalition of 40 political and civil society groups which had created the tansiqiyyat five years earlier, also formed the National Council for Support of the February 20 Movement (Conseil national de soutien au mouvement du 20 février). ${ }^{4}$

While most observers quickly realised that the new Constitution would leave the Makhzen's ${ }^{5}$ powers mostly intact, the concessions in terms of giving official status to the Amazigh language and the pardoning of political prisoners by the King in April 2011 meant that the King had taken some of the wind out of the sails of the F20M supporters.

The reasons for the decline of the F20M can therefore be summarised as follows: the monarchy's rather favourable and swift response in terms of announcing a new constitution, the decrease in the number of protest marches, the internal tensions within the movement (and especially the withdrawal of the Islamist movement al- 'Adl wa-l-Ihsan (AWI - Justice et Bienfaisance, or Justice and Charity Organisation) from F20M in December 2011), the refusal to elect F20M representatives, which led to a 'strategic paralysis', the smear campaigns against the activists by 'young royalists' (who created a group called March 9 Movement), as well as the Makhzen's surveillance and infiltration activities, and finally, the election of the PJD into government, which left many F20M activists with the feeling that their movement and cause had been taken away from them. In

3 Benchemsi, 'Morocco's Makhzen' 203-4. For the case of water privatisation and social mobilisation in Casablanca, see Mohamed Said Saadi, 'Water Privatization Dynamics in Morocco: A Critical Assessment of the Casablancan Case', Mediterranean Politics 17 (2012) 3: 376-93.

4 Benchemsi, 'Morocco's Makhzen', 216.

5 Makhzen refers to the power structures and patronage networks surrounding the monarchy. For the interviewees, this is the power structure or system that governs the country in practice, rather than the (elected) government. 
addition, the regional context including the armed conflicts in Syria and Libya contributed to fears of national disintegration on the part of many Moroccans if the protests would continue. In short, after less than a year's time, the F20M no longer existed. ${ }^{6}$

However, while many activists were left disappointed and demotivated, others continued their struggles by joining other groups (including the PSU party (Parti socialiste unifié), which offered one-fifth of its congress seats to F20M activists in December 2011), ${ }^{7}$ or creating new ones. The new groups included the Student Union for the Change of the Education System, known as UEX (Union des étudiants pour le changement $d u$ système éducatif) and the Theatre of the Oppressed (Théâtre de l'opprimé; Massreh el-mahgour), both established in 2012, as well as the Prometheus Institute for Democracy and Human Rights (Institut Prometheus pour la démocratie et les droits humains) set up in 2013, and others. ${ }^{8}$

6 Sarah Larik, 'Maroc: cinq ans après le Mouvement du 20 février, la jeunesse a-t-elle arraché ses droits?' Middle East Eye (édition française), 19 February 2016, accessed 6 June 2017, http://www.middleeasteye.net/fr/reportages/maroc-cinq-ansapr-s-le-mouvement-du-20-f-vrier-la-jeunesse-t-elle-arrach-ses-droits; Benchemsi, 'Morocco's Makhzen', 219-27. Benchemsi on page 226 describes how the lack of organisational structure and legitimate leadership in the local groups led them to be hijacked by their most radical members. This gradual radicalisation of the movement in turn led to a decrease in public support. See the Privacy International country page for Morocco for numerous examples of the government's use of Internet monitoring and surveillance activities targeting political activists and journalists (accessed 7 June 2017, https://www.privacyinternational.org/node/971). See also Samia Errazouki, 'Under Watchful Eyes: Internet Surveillance and Citizen Media in Morocco, the Case of Mamfakinch', The Journal of North African Studies 22 (2017) 3: 361-85.

7 Benchemsi, 'Morocco's Makhzen', 231; but Ghassan Wail El Karmouni, 'Mouvement du 20 février: Quels enseignments à tirer pour la gauche marocaine?' document dated 12 March 2012, accessed 7 June 2017, https://www.rosalux.de/ fileadmin/rls_uploads/pdfs/Themen/Arabellion/20120315_ghassan_wail_maroc. pdf, in footnotes 28 and 29, points out that only ten former F20M activists joined the PSU national council and no one joined the political bureau. Furthermore, the established party members reportedly continued their 'paternalistic' discourses towards them and some tried to contain them, hamper their initiatives, or even discredit them.

8 Larik, 'Maroc.' See also Assia Boutaleb, 'The Narrow Path: Acts of Citizenship by the Arab Youth: Lessons from Egypt and Morocco', in The Crisis of Citizenship in the Arab World, eds. Roel Meijer and Nils Butenschøn (Leiden: Brill, 2017), 481. The UEX was created to discuss and propose reforms to the Moroccan educational system. One of its main initiatives is the Popular University which is open to all, and mostly organised in public spaces such as parks. Similarly, the Theatre of the Oppressed holds plays in public spaces on issues such as corruption, racism, and violence against women. The Prometheus Institute works to promote 
Indeed, scholars and observers agree that while the institutional gains brought about by the F20M are limited, and state-society relations entered a new phase of repression, the events of 2011 did bring about a fundamental change in the relations between the citizen and the state in Morocco. Citizens are no longer afraid of the Makhzen, both at the discursive and physical level - i.e. both in terms of what they dare to say in public, as well as in terms of occupying public space for sit-ins and protests. ${ }^{9}$

In addition, the underlying grievances that fuelled the 2011 protests are still in place: high levels of corruption (in Transparency International's Corruption Perception Index 2016, Morocco is ranked 90th, down from 52nd in $2002^{10}$ ), unemployment, and popular dissatisfaction with public services. All of these can be subsumed under the term hogra, a colloquial Derija Arabic term for deprivation of dignity because of official abuses, nepotism, corruption, and marginalisation. ${ }^{11}$

values of citizenship and human rights, as well as the monitoring and evaluation of public policies, especially those concerning youth. Similarly, the group 'One Hour of Reading' organises public reading sessions followed by a discussion on current issues. The 'Collectif Aswat' works on defending LGBT rights in Morocco, and is mostly active on social media.

9 Larik, 'Maroc'; Benchemsi, 'Morocco's Makhzen', 221; Francesco Cavatorta, 'Morocco: the Promise of Democracy and the Reality of Authoritarianism', The International Spectator 51 (2016) 1: 91; Anja Hoffmann and Christoph König, 'Scratching the Democratic Façade: Framing Strategies of the 20 February Movement', Mediterranean Politics 18 (2013) 1: 1-22. For a good overview of so-called 'revenge arrests' against activists, see Maati Monjib, 'Morocco's Illiberal Regime and Fragmented Political Society', Arab Citizenship Review 10, EUSPRING (October 2015), no page numbers.

10 Benchemsi, 'Morocco's Makhzen', 230 and https://www.transparency.org/ news/feature/corruption_perceptions_index_2016 (accessed 7 June 2017).

11 Reuters, 'Thousands of Moroccans rally against corruption', Middle East Eye, 18 May 2017, accessed 7 June 2017, http://www.middleeasteye.net/news/thousands-north-morocco-rally-against-corruption-622375250; James Sater, 'Patronage and Democratic Citizenship in Morocco', in The Crisis of Citizenship in the Arab World, eds. Roel Meijer and Nils Butenschøn (Leiden: Brill, 2017), 168-9. For a discussion of the term hogra, see Abdelmajid Hannoum, 'Tangier in the Time of Arab Revolutions: An Ethnopolitical Diary', The Journal of North African Studies 18 (2013) 2: 274-5. For data on corruption and (dis)satisfaction in/with the health and education sectors in Morocco, see Hana Brixi et al., Trust, Voice and Incentives: Learning from Local Success Stories in Service Delivery in the Middle East and North Africa (Washington DC: The World Bank, 2015): figure 0.4 on p. 7 and figure 1.7 on p. 26 (corruption), figure 1.5 on p. 25 (satisfaction levels), figure 2.8 on p. 43 (rural-urban inequities in access to health services). See also Nabil Mouline (ed.), Le Maroc vote: Les élections législatives en chiffres (1963-2011) (TAFRA), 45 for some relevant results of the Afrobarometer survey 2013 in Morocco; e.g., 75 per cent of those surveyed reported finding it difficult to get hospital treatment. 
This point is vividly illustrated by the protests that broke out both in social media and on the streets following the King's pardoning of a Spanish paedophile in the summer of 2013. While the street protests were violently dispersed by police forces, the King was forced to reverse his decision. ${ }^{12}$

Similarly, current protests in the historically neglected and marginalised northern Rif region are the largest since the F20M protests in 2011. They were triggered by the death of a fishmonger in Al Hoceima in October 2016, who was crushed inside a garbage truck while trying to salvage his fish that had been confiscated by police. Since then, demonstrators have been demanding more and better public services and railing against corruption, repression and unemployment. A grassroots movement, the Popular Movement (al-Hirak al-Sha'bi) has emerged, led by Nasser Zefzafi, who was arrested at the end of May 2017 on charges of 'attacking internal security'. Zefzafi was also put on trial for having interrupted the sermon of an imam in the main mosque of the city, accusing him of inciting the congregation against the protest movement. Scores of other protesters have been arrested as well. ${ }^{13}$ As Mohammed Masbah points out in an online column, 'the protests have coincided with, and were sparked by, the six-month political deadlock that began after elections in October. The absence of a government since then has hindered the possibility of a genuine engagement with protesters and their demands. It has also left a void that was filled by the Ministry of Interior using repressive measures . . '14

As a report by Middle East Eye points out, 'fishmonger Mouhcine Fikri's death has become a symbol for frustrations about official abuses and revived the spirit of the F20M that led pro-democracy rallies in 2011 and prompted King Mohammed VI to cede some of his powers'. ${ }^{15}$ While demonstrations were initially confined to the Rif, the country is now witnessing a spate of violence in Al Hoceima and the Rif region, as well as in the country's largest cities of Casablanca, Rabat, Marrakech, Meknes

\footnotetext{
12 Larik, 'Maroc'.

13 MEE and agencies, 'Thousands Rally in Morocco for Release of Zefzafi and Ending Corruption', Middle East Eye, 3 June 2017, accessed 7 June 2017, http:// www.middleeasteye.net/news/thousands-rally-north-morocco-release-zefzafi-andend-corruption-914957953; Amnesty International, 'Morocco: Rif Protesters Punished with Wave of Mass Arrests', 2 June 2017, accessed 7 June 2017, https://www.amnesty.org/en/latest/news/2017/06/morocco-rif-protesters-punis hed-with-wave-of-mass-arrests/.

14 Mohammed Masbah, 'What Morocco's Monarchy Should Do Instead of Repressing Protesters', Middle East Eye, 19 May 2017, accessed 7 June 2017, http://www.middleeasteye.net/columns/moroccos-rif-protests-are-about-corrupti on-and-abuse-power-1658399521.

15 MEE and agencies, 'Thousands Rally in Morocco'.
} 
and others. Live footage shows several thousand people marching in each of these demonstrations. ${ }^{16}$ Current events thus add to the topicality of this chapter, as it aims to further our understanding of how and why 'ordinary citizens' mobilise to demand their rights from the state.

There is now quite a substantial body of scholarly work on the F20M, including on its use of social media, the constitutional reform it brought about, and the reasons for its decline. ${ }^{17}$ However, not much is known about the activities of former F20M activists and other young Moroccans since 2011, and in particular about their search for alternative understandings and practices of citizenship. How did they keep the 'spirit' of the F20M alive and how are their 'acts of citizenship' claiming

16 Fatima-Zohra El Malki, 'Morocco's Hirak Movement: The People Versus the Makhzen', Jadaliyya, 2 June 2017, accessed 7 June 2017, http://reviews.jadaliyya. $\mathrm{com} /$ pages/index/26645/moroccos-hirak-movement_the-people-versus-the-makh.

17 This body of work includes among others: Mounah Abdel-Samad, 'Why Reform not Revolution: A Political Opportunity Analysis of Morocco 2011 Protests Movement', The Journal of North African Studies 19 (2014) 5: 792-809; Fadma Ait Mous, Olivier Deau, and Maâti Monjib, 'The Debates On Citizenship in Morocco: Social Movements and Constitutional Reform', Euspring Working Paper 4, undated; Benchemsi, 'Morocco's Makhzen', 199-235; Ahmed Benchemsi, 'Morocco: Outfoxing the Opposition', Journal of Democracy 23 (2012) 1: 57-69; Mounia Bennani-Chraïbi and Mohamed Jeghllaly, 'La dynamique protestataire du Mouvement du 20 février à Casablanca', Revue française de science politique 62 (2012) 5: 867-94; Sylvia I. Bergh and Daniele Rossi-Doria, 'Plus ça Change? Observing the Dynamics of Morocco's “Arab Spring” in the High Atlas', Mediterranean Politics 20 (2015) 2: 198-216; Lenie Brouwer and Edien Bartels, 'Arab Spring in Morocco: Social Media and the 20 February Movement', Afrika Focus 27 (2014) 2: 9-22; Matt Buehler, 'Continuity through Co-optation: Rural Politics and Regime Resilience in Morocco and Mauritania', Mediterranean Politics 20 (2015) 3: 364-85; Emanuela Dalmasso, 'Apolitical Civil Society and the Constitutional Debate in Morocco', in Informal Power in the Greater Middle East: Hidden Geographies, eds. Luca Anceschi et al. (London: Routledge 2014), 145-58; Thierry Desrues, 'Moroccan Youth and the Forming of a New Generation: Social Change, Collective Action and Political Activism', Mediterranean Politics 17 (2012) 1: 23-40; Thierry Desrues, 'Mobilizations in a Hybrid Regime: The 20th February Movement and the Moroccan Regime', Current Sociology 61 (2013) 4: 409-23; El Karmouni, 'Mouvement'; Driss Magharoui, 'Constitutional Reforms in Morocco: Between Consensus and Subaltern Politics', Journal of North African Studies 16 (2011) 4: 679-99; Malka, 'Power and Authority', 59-78; Adil Moustaoui Srhir, 'Le mouvement 20 février au Maroc: entre l'autolégitimation et la délégitimation de l'état. Une analyse critique du discours', Nómadas 49 (2016), no page numbers, accessed 7 June 2017. http://dx.doi.org/10.5209/rev_NOMA.2013.v39.n3.48322; for an account of women's role in the F20M, see Abdellatif Zaki, 'Reflections on the 20-February Movement: Hope Renewed, Hope Frustrated for Women', in Women's Movements in Post- 'Arab Spring' North Africa, ed. Fatima Sadiqi (New York: Palgrave Macmillan US, 2016), 299-312. 
public spaces? How do they understand the concept of citizenship as compared to the state's discourse? What are the state's reactions to their activities, and how do the groups in turn respond to them? Finally, what, if anything, does the 2011 Constitution mean to these activists? These are the questions we aim to address in this chapter. By doing so, we aim to update and deepen the analysis started by some scholars into how young independent activists are 'engaged in processes of new meaning making, connecting the local with the global, and at the same time, developing their citizenship skills' ${ }^{18} \mathrm{We}$ also want to probe the wider argument that opportunities to engage in political activism and practice political citizenship are limited in Morocco due to deep-seated systems of patronage and the relatively stable consensus around the King. ${ }^{19}$

Following the body of critical studies on citizenship, we adopt the lens developed by Engin Isin to focus on the acts through which subjects constitute themselves as citizens, as those to whom the right to have rights is due. This constitutes a shift from the institution of citizenship (as a legal status of membership in the state) and the citizen as individual agent to acts of citizenship, i.e. collective or individual deeds that rupture social-historical patterns. ${ }^{20}$ Isin defines 'acts of citizenship as those acts that transform forms (orientations, strategies, technologies) and modes (citizens, strangers, outsiders, aliens) of being political by bringing into being new actors as activist citizens (claimants of rights and responsibilities) through creating [or transforming] new sites and [stretching] scales of

18 Brouwer and Bartels, 'Arab Spring in Morocco', 20, citing W. Lamer, 'Twitter and Tyrants: New Media and its Effects on Sovereignty in the Middle East', Arab Media and Society 16 (2012): 10. See also Assia Boutaleb, 'The Narrow Path', 471-87; and the contribution by Dörthe Engelcke on the Sada Middle East Analysis site of the Carnegie Endowment for International Peace ('Morocco's Changing Civil Society', 7 January 2016, accessed 28 April 2017, http://carnegieendowment. org/sada/?fa=62417). See also Taieb Belghazi and Abdelhay Moudden, 'Ihbat: disillusionment and the Arab Spring in Morocco', The Journal of North African Studies 21 (2016) 1: 48. They call for more research on the dynamics generated by political failures and their impact on both demobilisation and re-mobilisation of social movements. See also Joseph Hivert, 'Se désengager du mouvement du "20 février": Le cas des étudiants du supérieur de la coordination de Rabat', European Journal of Turkish Studies 17 (2013): 13ff, accessed 28 April 2017, http://ejts.revues.org/4811, for a detailed ethnographic account of F20M activists' disengagement.

19 Sater, 'Patronage', 156.

20 Egin F. Isin and Greg M. Nielsen, 'Introduction: Acts of Citizenship', in Acts of Citizenship, eds. Engin F. Isin and Greg M. Nielsen (London: Zed Books, 2008), 2; and Engin F. Isin, 'Theorizing Acts of Citizenship', in Acts of Citizenship, 16. 
struggle'. ${ }^{21}$ We argue in this chapter that the acts of former F20M activists constitute such 'acts of citizenship' and that this concept can help explain how the activists enact themselves in solidaristic, agonistic or alienating modes of being with each other. ${ }^{22}$ More broadly, by adopting this theoretical lens, we aim to understand how former F20M members 'act and perform when contesting the prevalent citizen regimes and when developing new experimental citizenship forms'. ${ }^{23}$

\section{INTERVIEWS}

\section{Methodology}

Our research methodology relies on three weeks of fieldwork in Morocco in February 2017 by the second author, during which interviews were held with a total of 24 activists in Rabat, Casablanca and Tangier. Most of the interviewees were engaged in the F20M and/or with the protests against Amendis, the French company in charge of providing water and electricity in Tangier, and its practice of raising prices, and subsequently joined or set up new groups. Table 4.1 below gives an overview of the interviewees' main affiliations. ${ }^{24}$ For the sake of ensuring their anonymity, in the text we refer to the number of the interviewees in our list rather than giving his/ her name.

The interview guide for the semi-structured interviews included questions on the definition and experiences of citizenship and acts of citizenship; the nature of the spaces and activities used to perform 'acts of citizenship'; the discursive as well as physical reactions of state authorities towards the groups' actions; and finally, the interviewees' views on the 2011 Constitution in terms of the extent to which it is granting more rights and possibilities to claim rights (e.g. with regard to the right to submit petitions etc.).

It is clear that by relying heavily on interviews with a group of respondents in the main cities of Morocco that was sampled using a snowball

21 Isin, 'Theorizing Acts of Citizenship', 39; and Engin F. Isin, 'Citizenship in Flux: The Figure of the Activist Citizen', Subjectivity 29 (2009) 1: 383.

22 Isin, 'Theorizing Acts of Citizenship', 37-8.

23 Roel Meijer, 'Citizenship, Social Pacts, Authoritarian Bargains, and the Arab Uprisings', in The Crisis of Citizenship in the Arab World, eds. Roel Meijer and Nils Butenschøn (Leiden: Brill, 2017), 95.

24 The second author contacted a representative of Amendis as well as a member of AWI, but both refused to talk to her. 


\section{Table 4.1 List of interviews and research respondents - numbers and affiliations}

\begin{tabular}{ll}
\hline Interview No. & Affiliations \\
\hline 1 & Lawyer defending activists who were arrested during the protests \\
& and activist in F20M \\
2 & Young activist arrested in Tangier during the Amendis protests \\
3 & Journalist for Anwal website and activist in F20M \\
4 & Member of PSU and activist in F20M \\
5 & Involved in the anti-Amendis mobilisations in Tangier and activist \\
& in F20M \\
6 & A citizen from Birr Chifa neighbourhood in Tangier involved in the \\
7 & anti-Amendis mobilisations \\
8 & Activist in F20M and participated in anti-Amendis protests in \\
9 & Tangier \\
& Activist in F20M and member of ATTAC Maroc in Tangier \\
10 & Member of Prometheus Institute for Democracy and Human Rights \\
& and F20M \\
11 & Member of Prometheus Institute for Democracy and Human Rights \\
12 & and F20M \\
13 & Activist in Amazigh Movement (Tawada) and F20M \\
14 & Journalist and activist in F20M \\
15 & Activist in UEX and F20M \\
16 & Activist in F20M \\
17 & Member of Theatre of the Oppressed and F20M \\
18 & Activist in F20M and member of ATTAC Maroc \\
19 & Member of One Hour of Reading, Association Dibaja, and F20M \\
20 & Activist in F20M and AMDH \\
21 & Activist in F20M and other organisations \\
22 & Working for an international NGO in Morocco \\
23 & Activist in Amazigh Movement, UEX, and F20M \\
24 & Activist in UEX, Collectif Aswat, and F20M \\
Member of Theatre of the Oppressed and F20M \\
Activist in F20M and member of youth section of FMAS (Le Forum des \\
Alternatives Maroc)
\end{tabular}

Note: Interviews 1 and 6 were not cited in this chapter.

sampling technique, this contribution gives a view that is biased in favour of well-educated, secular, youth. ${ }^{25}$ Indeed, many of the young secular activists in the F20M first formed in 2009 as a group of Internet users

25 Conducting a thorough analysis of social media postings was beyond 
defending individual freedoms, especially after the MALI incident. ${ }^{26}$ The most active members of this 'underground community' were middle class students or recent graduates from politically engaged families in Casablanca and Rabat. They engaged in online advocacy campaigns to defend victims of police abuses and corrupt (and nepotistic) government practices. Some of them had links with the AMDH and radical leftist parties. While the latter helped with logistics during the F20M protests (e.g. by letting them use their offices), the F20M kept its independence from established organisations. ${ }^{27}$ Our interviewees are thus mostly part of what Driss Maghraoui calls 'subaltern politics' which is 'outside the control and orbit of the authoritarian state and quiescent political parties with a generally corrupt and cooptable leadership'. ${ }^{28}$ However, as we can see from Table 4.1, a few of our respondents are members of (leftist) political parties such as the PSU.

The choice of Tangiers in addition to Rabat and Casablanca as a fieldwork location was motivated by the observation that the F20M in Tangiers was arguably the best organised group in the country. This is mainly because of its history of close coordination between leftist parties, Islamist organisations, and labour unions in organising protests against the US invasion of Iraq in 2003, and the Israeli attacks on Lebanon in 2006 and Gaza in 2009. According to Benchemsi, 'Tangiers was also the only big city in Morocco where Islamists were invited to participate in the tanseeqiat [tansiqiyyat] against rising prices'. The cross-partisan

the scope of this chapter, but it would have undoubtedly enriched the findings presented here.

26 The Alternative Movement for Individual Freedoms (known under its French acronym MALI) was launched on Facebook on 2009, and it organised a public daytime picnic during the month of Ramadan (which is a legal offence in Morocco) so as to open a debate on the freedom of conscience. The six activists were prevented from holding the picnic by a heavy police force and brutally interrogated. The event generated a massive conservative uproar and dominated the news for several days. Two thousand people joined the MALI Facebook page within two days, and for many leaders of the later F20M, this was a catalyst event that propelled them into political activism. See Benchemsi, 'Morocco's Makhzen', 206-7 and also Srhir 'Le Mouvement', for an account of pre-2011 mobilisations.

27 Benchemsi, 'Morocco's Makhzen', 205-6. As Adria K. Lawrence observes, 'many first movers [people who plan, publicise and initiate anti-regime protest] came from families that had previously suffered at the hands of the regime for their political activities'. See, Adria K. Lawrence, 'Repression and Activism among the Arab Spring's First Movers: Evidence from Morocco's February 20th Movement', British Journal of Political Science 47 (2017) 3: 3 and 8. See also Hivert, 'Se désengager', 1-30.

28 Magharoui, 'Constitutional Reforms', 687. 
collaboration also supported ATTAC Maroc in mobilising big crowds for daily demonstrations against Amendis. ${ }^{29}$ The eight interviews conducted with respondents in Tangiers thus focused mostly on their experiences in the anti-Amendis protests, which have flared up now and then for the last few years. The research more generally took place in a period in which there were regular clashes between protesters and state authorities in Al Hoceima and neighbouring areas, and this fact may have influenced the responses.

\section{Capturing the Public Space: 'Taking (to) the Street'}

This section presents the findings related to the claiming of public space as an 'act of citizenship' itself. Our interviews confirm that since the F20M, the occupation of public space has become 'normal'. ${ }^{30}$ As Interviewee 19 said, 'since 2011 things changed. The first thing is that people are not afraid anymore to take to the street and the second thing is that people are actually interested to participate. They are aware of their rights and understand the political issues'. This is echoed by Interviewee 4, who observed that in Tangier, "people were not afraid anymore and people became aware of claiming their rights ... People understood that in this country you cannot get anything done without going to the street (prendre la ruel tayakhdu al-shari ')'. Interviewees 4, 7, and 8 also referred to despotism, corruption and loss of trust in the government and the local authorities to explain this trend.

This appropriation of the public space (the real and virtual one) also gave rise to expressions of 'acts of citizenship'. In the words of Interviewee 13, who is active in the UEX, 'freeing the public space [i.e. liberating it from state control] and occupying it is how we express our citizenship (citoyenneté, muwatana). We are transforming this public space into an agora of debate with people coming from different social classes and backgrounds.' Similarly, Interviewee 21 observed that 'all spaces are invaded with debate and discussion ... when we are in the street people now come and listen and speak which they were not used to do before 2011.' This former F20M activist presents this public discussion of solutions as major lessons he and his contemporaries learnt from their 2011 experience:

29 Benchemsi, 'Morocco's Makhzen', 214-15, quote on p. 214. See also Hannoum, 'Tangier', 273.

30 For a historic overview of social protests in Morocco and their use of public space, see also Abderrahmane Rachik, Les Mouvements de protestation au Maroc: de l'émeute à la manifestation (Rabat: Forum des Alternatives Maroc, 2014). 
What we discovered after 2011 is that the youth speak about politics but hate the political parties. At the same time, people were protesting about lots of things but F20M was not bringing any propositions or alternatives. As they used to say, 'F20M knows [only] what they do not want.' I think in our activities, we try to establish new spaces to bring alternatives through debates and sharing.

Interviewee 16 frames these new forms of organising as 'new expressions of citizenship not in the formal "normal" processes (parties and trade unions) but in new ones that are expressed through the public space'. He went on to explain that these new types of activities, like Philosophy in the Street and Theatre in the Street represent a new approach to citizen participation developed by a younger generation which stand in contrast to (and sometimes in conflict with) the 'traditional models of participation' by the older generation of activists.

\section{Socio-economic Rights versus Political Rights}

Our findings also show a clear tendency by the activists to distinguish between 'acts of citizenship' to claim socio-economic rights, and those that are claiming political rights and changes in the political system. In their minds, the latter type of claim seems to have been dominant in 2011 but is now much more difficult to make (at least at the time of fieldwork - the current protests, i.e. in June 2017, may mean that this is now changing).

As Interviewee 5 puts it in the context of Tangier (similar to Interviewees 7 and 16):

there are no more political protests in Morocco [to change the Constitution or the government] but all the social issues and problems are in the street now. A lot of people who got their first experience in F20M led the demonstration against Amendis, and gave their support and experience to better organise these spontaneous protests. They did so because they were concerned as citizens about the expensive bills. And it was also an opportunity to go back to [i.e. revive] the street after the calm in the wake of the 2011 protests. The difference between the F20M and Amendis protests is that the second one is about a social issue that affects the people in their pockets [money], so it is easy to mobilise them for it. People were willing to take the street in order to resolve this problem.

Interviewee 16 points out that in general, mobilisations are fragmented around professional or other social groupings: 'we see categories of society that have common interests emerging in the public space: teachers, students, and so on. We see a kind of coordination in all these categories. People can gain some rights but this lack of solidarity and clear political frame is a weakness in itself as well.' 
Indeed, this trend signifies the continuation of the dominant earlier modes of popular mobilisation. As Benchemsi points out, even though many of their activists were members of anti-Makhzen political organisations, "the success of ATTAC and the tanseeqiat (tansiqqiyyat) was largely based on their reputation as apolitical movements ... Up until 2011, Moroccan citizens were eager to protest against their economic conditions as long as it didn't mean directly challenging the monarchy. ${ }^{31}$ Moreover, protests over socio-economic issues have become the norm in Morocco since 2011. One estimate in 2014 suggested that Morocco witnesses approximately 50 unrelated demonstrations every day throughout the country. ${ }^{32}$

Nevertheless, as the former F20M activists are involved in many of these 'issue-based' protests, they are trying to insert a more political dimension into them. As Interviewee 15 explained, while the protesters with limited and specific demands just want to resolve their own problems and disappear from the street:

we have to be aware that those groups are supported and in lots of cases coordinated by groups of young people that were part of the F20M and learnt a lot there, so they are trying not to repeat the same mistakes [i.e. a lack of leadership, making vague and undefined political demands]. These groups try to link the demands of those protests with the slogans of the F20M such as dignity, freedom, and social justice. In Tangier for example, one of the slogans was: 'how are we considered as citizens if we don't have health or education?' (bech ehna mouwatinin, la sehha la ta'alim). The people who were involved with the F20M were able to make the link between the specific demands of those protesters with the large and political slogans of the F20M, however they could not give it a larger perspective as once the demands are realised the people stop going back to the street.

\section{The King}

A further interesting dimension is the distinction made between protesting against the government institutions as opposed to against the King. 'People are not going out to the streets to be against the state. Citizens go sometimes to the street to communicate directly with the King as they perceive him as the only one who can resolve their problems and not necessarily as someone who guarantees their rights as citizens' (Interviewee 12). Apart

31 Benchemsi, 'Morocco's Makhzen', 204.

32 B.S., 11 June 2014, 'Protest Culture in Morocco', The Economist, accessed 25 June 2017. http://www.economist.com/blogs/pomegranate/2014/06/protestculture-morocco. 
from pointing to the deep-rooted legitimacy of the King, ${ }^{33}$ this statement refers to the relative lack of direct communication channels between the King and the people, and the relative absence of trade unions and other societal groups and actors who used to serve as intermediaries. Similarly, Interviewee 15 observed:

citizens lost their trust in politicians and government institutions but they did not lose their trust in the King. In daily life everyone repeats 'they (politicians) are all thieves (voleurs/chefarra), Sidna (the King) is the only one working (in the people's interests).' You can observe this when a group of citizens protests about a specific problem. On their banners they ask the King to help them and find solutions and not anyone else.

He continued by saying that this distinction is in fact wanted by the Makhzen. 'The state propaganda is designed to push people to lose trust in all actors except the king. ${ }^{34}$ However, this trend is also reinforced by the repressive apparatus: 'People are aware that if they want to protect themselves they have to shout "long live the king" even if they are not convinced' (Interviewee 15).

\section{Activists' Notions of Citizenship}

In order to better understand the discursive linkages between various types of rights and the relationship with the state, it is useful to consider our findings on how the activists understand the notion of citizenship.

Many of our interviewees referred to a comprehensive notion of citizenship rights. For example, Interviewee 7 said, 'for me it does not include only political rights but also social and economic rights. Citizenship

33 Unlike the protest movements in Tunisia, Egypt and Libya, Moroccan activists in the F20M could not raise the demand for the head of state (i.e. the king) to go. Benchemsi cites three reasons for this. First, its long history gives the Moroccan monarchy a deep legitimacy. Second, the current king is not perceived as a tyrannical dictator by most of the population. Third, he is seen as a symbol of national unity which holds the ethnically and culturally diverse population together, and his departure might mean the disintegration of the nation and violent conflicts. In short, 'Morocco's activists are well aware that calling for the monarchy's demise would alienate the great majority of their followers'. See, Benchemsi, 'Morocco's Makhzen', 224-5, quote on pp. 224-5. See also Cavatorta, 'Morocco: the Promise', 89ff.

34 See also, Sater, 'Patronage', 159, 170-71, for the point that in the minds of the people, the King is juxtaposed with the perceived corrupt and ineffective bureaucracy, elected (sub-national) government(s), as well as established political parties. 
means the right to work, housing, education ... Dignity (karama) and social justice are the biggest citizenship problems in Morocco and the fight towards a real citizenship is still long.' The notion of dignity was also mentioned by Interviewee 21 (see also Interviewees 8 and 4): 'For me citizenship is dignity and it is a universal right to be respected as a human being with rights everywhere in this world. It is not related to the Moroccan flag or borders; those do not mean anything to me. It is also a rejection of hogra because the poor and the marginalised people have nothing but their dignity. This is why I like the slogan we used to shout in 2011: "We are citizens not subjects"" (ehnna mouwatinin machi ra'aya). This universal aspect of citizenship rights was also echoed by other respondents (Interviewees 10, 18, 23 and 24).

Some respondents only referred to the political dimension of citizenship. '[Citizenship] is the right to express our opinions, accept diversity and difference, to be able to live together in society where everyone has its own place. It is to live in a democratic society where each citizen has his/ her voice and express[es] his/her opinions and concerns' (Interviewee 12, see also Interviewee 3 ).

Others viewed citizenship as having mainly to do with access to and participation (moucharaka) in public decision-making. Interviewee 7 (similar to Interviewees 9 and 16) stated: '[Citizenship means] to have access to the state to decide about what the state should or should not do in terms of laws and policies . . . That the citizen can decide on the matters that affects his/her daily life ...35

The notion of accountability (redevabilitélmoussaala) was also mentioned, e.g. by Interviewee 15: 'What is important for me in that concept is my right to ask for the political and economic accountability of the people in power and my right to live with dignity, our right to be protected by the state.'

35 Interestingly, a World Bank-funded nano-survey with almost 20,000 responses conducted during March-April 2014 revealed that 71 per cent of those surveyed want to have access to public sector information, and 58 per cent want to participate in decision-making; however, 71 per cent also indicated that public information is relatively hard to access, and 84 per cent had no prior experience in public engagement. Less than half were aware of the right of citizens to present petitions or legislative motions. RIWI, 'RDIT'M measures citizen thoughts in Morocco for the World Bank's project on Open Data', 28 July 2014, accessed 7 June 2017, https://riwi.com/rdit-measures-citizen-thoughts-in-morocco-for-theworld-banks-project-on-open-data/. The dataset is available at https://finances. worldbank.org/Other/World-Bank-Morocco-Citizen-Engagement-Nano-Survey-/ $\operatorname{tg} 37-\mathrm{mj} 88 /$ data). Note that the organic laws on motions and petitions were only adopted in July 2016. 
On the other hand, for some activists, citizenship does not have much resonance at all. Interviewee 13 (active in UEX) said, 'we do not have an internal debate on that in our group. We do not question the concept itself. And I do not think that normal citizens in Morocco care about that, they are busy with their daily life. I am sure if you ask them they will say "the state belongs to it owners" (dawla dial maliha in Moroccan Arabic; or al-dawla li-l-ashabihim in standard Arabic). It means that the state is not theirs. For me it is an empty concept that does not mean much.' Later on he added, 'I think not even the state stopped one minute to think about what makes someone a full citizen in this country.'

This sentiment is also dominant in the responses we got to the question about the state's definition of citizenship.

\section{THE STATE}

\section{Citizens and Subjects}

Some interviewees went back to the distinction between citizens and subjects:

The state looks at us as subjects (sujets, ra'aya), not as people who have rights. In one protest I heard a representative of the Ministry of the Interior saying to protesters 'those human rights are spoiling you, if I was in charge I would starve all of you. You had enough bread [i.e. you are not hungry anymore] and now you think that you can rule [and ask for more rights]!' (Interviewee 12)

Similarly, according to Interviewee 24 , 'the state focuses a lot in its discourse on the duty part, because in its opinion the citizens are not fulfilling their duties (responsabilités, mass 'ouliates). And of course it is less focusing on the rights part because it means more problems to resolve.' Instead of rights, subjects are granted privileges, according to Interviewee 17; 'the state talks about your rights as if they are privileges (privilèges, imtiyazat) that institutions are giving you'.

Along with the notion of 'subjects', interviewees also mentioned other ways in which they believe the state is perceiving them which hint at a more neoliberal governmentality. According to Interviewee 8, 'I do not think that the state itself in its practice sees us as citizens, [but rather] it sees us as consumers and as people to be managed in a territory . . . It does not expect anything from us except to go to work, accept our conditions without claiming anything, and consume everything that it provides, such as political discourses or material goods.' To this, Interviewee 7 added, 
'the state wants us to respects the traffic rules, keep the beaches clean, and not use plastic bags, without giving us any rights'.

\section{Elections}

However, the dominant view among our interviewees was that the state's discourse emphasises the duty to vote in elections. As Interviewee 16 said, 'the state institutions are limited in their definition; citizenship is [limited to voting in] elections'. This is confirmed by Interviewee 15 (see also Interviewees 9, 10 and 23): 'If you do not vote you are not citizen, this is what the state thinks and what the king said in one of his speeches. ${ }^{36} \mathrm{He}$ continued by saying, 'this is itself depriving you from one of your rights as a citizen, namely to boycott the elections. This is dangerous, this is a definition based on the interest of the state in you as a voter . . It is dangerous because citizenship is reduced to a vote and this disregards all the other universal values that can make you a citizen.'

Our findings are confirmed by Moroccan scholar Maati Monjib, who argues that 'citizenship is mainly focused on elections and parties. In the official discourse, the right to vote and run for office remains the most important feature of citizenship, whereas political freedoms, social change, equality, dignity and economic justice - the main demands of the people in 2011 - tend to be marginalised. ${ }^{37}$

\section{Values and 'Civic Behaviour'}

Interviewee 16 also highlighted the current debate between secular and religious notions of citizenship in Morocco:

36 See the King's speech on the 54th anniversary of the 'King's and People's Revolution' in 2007, where he states, 'le vote est l'un des éléments clés de la citoyenneté responsable' ('voting is a key element of responsible citizenship'). Accessed 19 April 2017, http://www.maroc.ma/fr/discours-royaux/discoursde-sm-le-roi-mohammed-vi-à-la-nation-à-loccasion-du-54-ème-anniversaire-de. Similarly, the Makhzen presented the participation in the July 2011 referendum on the new Constitution as a civic and democratic duty (Srhir, 'Le Mouvement', no page number). In the throne speech of 2016, held just before the parliamentary elections, the King said, '[le] citoyen ... doit assumer ses responsabilités pour ce qui est de choisir les élus et de leur demander des comptes' ('the citizen must take his responsibilities and choose the elected politicians and ask accountability from them'). Accessed 19 April 2017, http://www.maroc.ma/fr/discours-royaux/ texte-integral-du-discours-royal-loccasion-de-la-fete-du-trone.

37 Monjib, 'Morocco's Illiberal Regime', no page number; see also Srhir, 'Le Mouvement', no page number. 
In schools the values of citizenship are not clear in our educational programs. There is the problem of [Arab and Berber] identity and a lot of confusion. For example: the values of modernity as democracy, rights and duties [which are different from] other values in the Islamic education such as subordination, respect of elders, etc. The state has no idea of the type of citizen that it wants. We give children contradictory values in the school. We want people to participate but with moderation and within the state's rules.

This statement is well illustrated by the notion of 'civic behaviour' (comportement civique) as defined in the High Council for Education's Strategic Vision for Reform 2015-2030. The definition emphasises attachment to religious and patriotic principles of the citizen's country, respect for the symbols of the nation, and his obligations towards the country (patrie) as well as his responsibilities towards himself, his family and his community. It ends in a rather neoliberal twist by saying that the citizen should be able to count on himself and show a real spirit of initiative. ${ }^{38}$

However, Interviewee 17 (similar to Interviewee 19) reminds us that 'the state' should not be seen as a monolithic or reified entity but that it consists of various parts, and that this in turn gives rise to various definitions of citizenship:

I do not think that the state has a proper definition of citizenship, even if what we learn in school is 'duties and rights'. [It] also depends on which part of the state we are dealing with. The Ministry of the Interior is not the CNDH (Le conseil national des droits de l'homme, the National Human Rights Council). Each of them has its proper definition and conceptualisation of what are the Moroccans' rights and duties.

We can thus observe quite different understandings of citizenship on the part of the state, but all of them limited in terms of granting rights.

38 Conseil supérieur de l'éducation, de la formation et de la recherche scientifique, 'Pour une école de l'équité, de la qualité et de la promotion: Vision stratégique de la reforme 2015-2030' (2015), 97, which in turn cites an extract of the royal letter addressed to the conference on 'civic behavior' (le comportement civique), organised in 2007 by the High Council for Education. Translated from French by the first author. As Muhammad Faour points out, 'teaching young students what it means to be citizens who participate in and contribute to their societies rather than subjects of the state who are taught what to think and how to behave is key to democratic progress'. See, Muhammad Faour, 'The Arab World's Education Report Card: School Climate and Citizenship Skills', Washington DC: Carnegie Middle East Center, Carnegie Endowment for International Peace, 3 (2012). According to Ennaji, however, 'since Morocco's independence until very recently, citizenship education has not been a central purpose of public education'. See, Moha Ennaji, 'Multiculturalism, Citizenship, and Education in Morocco', Mediterranean Journal of Educational Studies 14 (2009) 1: 8. 


\section{Tactical Responses: 'The Makhzen Acts Like God'}

We now turn to a discussion on the state's reaction to the activists' 'acts of citizenship'. Our interviewees confirmed the observations made in the Introduction, i.e. that the space for civil society and citizen mobilisation overall is rapidly shrinking. Most of them characterised their interactions as a 'cat and mouse game' (Interviewee 21), in which the state apparatus deploys seemingly unpredictable and random strategies, which are nevertheless following a certain internal logic. As Interviewee 17 put it, in our case [i.e. One Hour of Reading], they wanted to know who is behind us and . . . let us know that the space is not 100 per cent ours. They are just letting you use it for a reason, they will take it back when they want to.'

Interviewee 21 illustrated this point by saying:

when it is in the state's interests, they can let it go, for example in a period when [Minister of the Interior] Hassad was in conflict with [Prime Minister] Benkirane, they were not stopping our activities in the public space [i.e. the Philosophy in the Street], because our discourse has progressive values which were annoying the Islamists. They needed us at that particular moment to send a message to the PJD. But when this period ended, they started to stop us from time to time. ${ }^{39}$

According to Interviewee 13, in UEX, they are involved in a 'war of attrition' with the state: '[The local authorities] will use all their resources till we stop showing up one day. The state is very patient in those things; they are annoying us till one day we get tired and disappear.' This dynamic is described very poignantly by Interviewee 19: 'The repression can come back any moment depending on the political situation. The Makhzen acts like God: It gives with one hand and takes with the other, never sleeps, never forgets and rarely forgives.'

However, as was the case with the state's definition of citizenship, Interviewee 21 pointed out that 'the state system itself is not homogen[e] ous, most of the times it depends on the people who are in charge of the city, for example in Casablanca the Philosophy in the Street activities were not always stopped while in Marrakech they were forbidden' ${ }^{40} \mathrm{He}$ added

39 A similar dynamic seems to have taken place in Tangier between PAM and PJD deputies and councillors (according to Interviewee 8).

40 During the F20M protests, the police in the various cities also reacted differently - for example, it did not take any action in Casablanca and Rabat while in Marrakech, it violently cracked down on activists. See, Benchemsi, 'Morocco's Makhzen', 213. This could be because the activists in Marrakech were not backed by traditional political groups as was the case in Rabat and Casablanca. 
that these are not only institutional decisions but personal ones as well, depending on who is the governor, their own interpretations of the orders from the central authorities, etc. In Marrakech, the local authorities mobilised so-called 'thugs' (baltgayyiya; a term borrowed from the Egyptian context) to organise protests against other citizens who are protesting. This allows the local authorities to say that it is other citizens who are against the protesters, and that they (i.e. the local authorities) are only there to ensure public order. ${ }^{41}$ Indeed, our respondents (e.g. Interviewee 16) more generally mentioned the government's strategy to co-opt them into regime-friendly associations.

\section{Carrots and Sticks}

More generally, the state's strategy can be called one of 'carrots and sticks'. According to Interviewee 8, this 'is still and has been the strategy of the state since independence. And we can see it now from what is happening in Al Hoceima. The state keeps a low profile until people's anger comes out and then it starts the co-optation, and when the movement calms down the repression of the individual starts.' Interviewee 3 illustrates this for the case of the Amendis protests in Tangier:

I think that the authorities were very smart as usual. They let the people get out their anger in the street, while trying to identify who were behind this protest, and at the same time trying to negotiate a solution with Amendis. The challenge for the authorities was to manage the protests so they would not get big and politicised, and find a solution that can partly make people satisfied so they can go back to their homes.

\footnotetext{
41 This is a continuation of practices used in 2011. As Benchemsi points out, "each time a Feb20 local group announced a protest venue, "resident associations" suddenly mushroomed there, pledging to "defend" their neighborhood against "extremists" and "troublemakers". These were in fact pro-Makhzen goons, largely manipulated by local authorities ...' See, Benchemsi, 'Morocco's Makhzen', 220-1, quote on p. 221. Anti-F20M groups also spread rumors about the activists, making them out for 'anarchists' or 'homosexuals', or members of the Polisario, and 'Ramadan eaters', both in the social media as well as traditional media. See Brouwer and Bartels, 'Arab Spring in Morocco', 19; and Hannoum, 'Tangier', 276, 282. Hannoum reports vandalism and damage to shops and banks in Tangier on 20 February 2011 that were clearly the work of the Makhzen in an attempt to blame the movement for the violence and portray them as a group of destroyers and anti-royalists. See, Hannoum, 'Tangier', 277-80.
} 


\section{Avoiding Co-optation}

Having reviewed the state's strategies, how do the groups we studied deal with them? Interviewee 15 from the Theatre of the Oppressed explained that:

our relation with the state is based on respecting the law. We try to follow the law and try to change the law related to [the use of] public space. We are now involved in an advocacy initiative to change the law related to the public space. We do our best not to be in confrontation with the Ministry of the Interior, it's just a waste of energy.

Similarly, Interviewee 9 of the Prometheus Institute asserted that:

we have a good relation as partners, they know we produce serious reports based on real facts and research. We collaborate with most institutions, but we are sure that they [intelligence services] are following us, [to find out] with whom we work, on what, etc. We limit ourselves so as not to be in confrontation with the state [i.e. not to cross certain red lines] and try to stay independent financially.

A similar statement was made by Interviewee 24 in relation to FMAS (Le forum des alternatives Maroc). A Berber activist, Interviewee 11, mentioned that ' $[\mathrm{w}] \mathrm{e}$ do not have any problems in organising our actions. They [state authorities] do not see us as a danger.' In short, for most of the groups it is important to learn 'how to negotiate with the political actors and the state without being captured' (Interviewee 9).

Indeed, this learning process started already in 2011 during the constitutional reform process, during which the royal-appointed Consultative Commission for the Constitutional Reform invited F20M members to participate in its consultations with civil society organisations and political parties. All of them refused, given that they considered the process undemocratic. ${ }^{42}$ As Sater points out, most of 'Morocco's middle class and opinion makers, with their resources at universities, civil society, media, and the private sector, [had] already been absorbed into networks of patronage' by the time of the F20M protests (e.g. through their incorporation into the leadership of regime-friendly new political parties such as the Authenticity and Modernity Party - PAM, established in 2009). ${ }^{43}$ Our respondents are thus acutely aware of this dynamic and are searching for

42 Sater, 'Patronage', 170; Benchemsi, 'Morocco's Makhzen', 218; El Karmouni, 'Mouvement', footnote 23.

43 Sater, 'Patronage', 168; Hannoum, 'Tangier', 286-7, confirms this point. 
ways in which they can exploit the limited space for civic mobilisation without being co-opted.

\section{'The Constitution Has Nothing to Do with Reality'}

As for their views on the 2011 Constitution, most respondents dismissed it as being irrelevant to their struggles, mainly because they do not see its articles on popular petitions and other forms of protest being applied (Interviewees 2, 3, 5, 8, 11, 15, 18, 20, 21, 23). As Interviewee 19 put it, 'to be honest, we all know that the Constitution is not only far from being perfect but has nothing to do with the reality'. Instead, as Interviewee 12 observed:

the practice is the real constitution in Morocco and this is what the monarchy does, namely to create rituals [such as the ' $b a$ ' $y a$ ' or oath of allegiance ritual], boundaries [self-censorship and self-regulation by both elected politicians and civil society] and taboos. They are respected by everyone without any questioning. Now who has the political power in Morocco to say to the King that he is not respecting the Constitution and to mobilise people around it? No one, and we all know that including the King himself.

Rather, as has been observed by scholars as well but perhaps not been put in such crude terms, 'you have to understand that this Constitution was written for the international opinion and the intellectual masturbation of the Moroccan elite, not for the people themselves. People can talk to us on TV about it but no one cares' (Interviewee 13).

Others were less dismissive about the Constitution but still sceptical about its potential role in opening up spaces for 'acts of citizenship'. According to Interviewee 16 (see also Interviewee 14):

the Constitution gave us some rights but with limits ... The Constitution in my opinion was more interested in models of participation than the quality of this participation. We will create models that the state will implement without any ownership from the citizens, it means that we will participate as they want us to do. They win because they are more interested in numbers of people who participate ... The challenge for us as activists now is to open the public space and this we did not yet succeed to do.

To end on a more hopeful note, Interviewee 24 said:

I cannot say that the Constitution is perfect, but in this text there are Articles that we can use to create more participation opportunities for citizens. I think that we should stop seeing the change as a goal but as a process, and this process is not perfect ... There are a lot of Articles like the one on participation at the 
local level with the municipalities that civil society has to work and advocate for in terms of getting organic laws passed to make participation possible for citizens at the local level.

\section{CONCLUSION}

To conclude, our findings show that former F20M members have developed new forms of organising that claim the public space through 'acts of citizenship'. However, the object of such acts is often a certain (perceived or real) socio-economic right (e.g. access to affordable water services), rather than a specific political right (e.g. freedom of expression, or free and fair elections). In other words, mainly due to the strong popular legitimacy of the King and the Makhzen, social mobilisations in Morocco were - at least until recently - fragmented around professional or other social groupings, though former F20M activists sometimes managed to inject a more political citizenship dimension to such protests. We also found that the activists' understanding of citizenship is mostly a universalist one and linked to notions of dignity and participation in public decision-making processes (outside elections). This understanding stands in contrast to the state's discourses on citizenship, which focuses on citizens as subjects with duties (in particular, to vote in elections) who are occasionally granted privileges, not rights. However, it also became clear that the state is not monolithic, and that various entities within the state may convey different discourses. This tendency is mirrored by the various location- and person-dependent repressive practices by state agencies towards the activists. However, generally, the dominant tendency is for the state to try to wrong-foot the activists and co-opt them into regime-friendly associations, followed by the repression of individual activists. The activists in this study are thus continuously searching for ways to avoid (too much) co-optation while still claiming public spaces for their acts of citizenship. Given their mostly negative views on the potential of the new Constitution to formally open up such spaces, this dynamic will most likely continue, unless their more political definition of citizenship becomes more embedded in Moroccan society, as recent events may imply. ${ }^{44}$ Our findings thus illustrate Étienne Balibar's

44 A further dimension of 'acts of citizenship' which provides fertile ground for further research is that of 'cultural citizenship' in Morocco. See Mohamed El Marzouki, 'Citizens of the Margin: Citizenship and Youth Participation on the Moroccan Social Web', Information, Communication and Society 19 (2016) 1: 1-15, accessed 28 April 2017, http://dx.doi.org/10.1080/1369118X.2016.1266373, for a 
observation that 'the birth of the citizen as subject of power [subversive of authority] does not mean the disappearance of the subject as a subject to power [submissive to authority]'.45

study of the production/consumption of user-generated video as articulations and critiques of conditions of marginality which constitute new political subjectivities committed to resistance and struggle (13-14). See also, Zakia Salime, "I Vote I Sing": The Rise of Aesthetic Citizenship in Morocco', International Journal of Middle East Studies 47 (2015) 1: 136-9.

45 Cited in Engin F. Isin, 'Citizenship Studies and the Middle East', in The Crisis of Citizenship in the Arab World, eds. Roel Meijer and Nils Butenschøn (Leiden: Brill, 2017), 515-16 (emphasis in original). 